\title{
GIS-ASSISTED FLOOD HAZARD ASSESSMENT AND MAPPING IN SELECTED AREAS IN ZAMBALES
}

\author{
A.M. Paz-Alberto ${ }^{1,}{ }^{*}$, E.E. Camaso ${ }^{1}$, G.P.L. Abella ${ }^{1}$, C.R. Genaro ${ }^{1}$, and C.H.E.A. De Guzman ${ }^{1}$ \\ ${ }^{1}$ Institute for Climate Change and Environmental management, Central Luzon State University, Science City of Munoz, Nueva \\ Ecija, Philippines
}

Commission IV

KEY WORDS: flood, hazard, assessment, mapping, GIS, field validation

\begin{abstract}
:
The Philippines experiences an average of 20 cyclones per year which cause flooding in many parts of the country and Zambales is one of them. In August 2013, Typhoon Labuyo hit the province that affected most of its municipalities and placing the town of Masinloc under the state of calamity due to occurrence of flood. Likewise, in September 2018, Typhoon Ompong hit the province of Zambales and brought heavy rains and floods to the municipalities of Sta. Cruz, Candelaria, Masinloc, and Palauig. Hence, this study was conducted to generate flood hazard maps in the northern municipalities of Zambales: Sta. Cruz, Candelaria, Masinloc, and Palauig using Geographic Information System through raster calculator. Weights of the factors considered in generating flood hazard susceptibility map, namely, elevation, slope, soil type, land classification, and distance from the river, were drawn from ten (10) experts and undergone Analytical Hierarchy Process (AHP). Field validation was also conducted to test the accuracy of maps generated. Flood hazard susceptibility was categorized into four (4) namely high, moderate, low, and no susceptibility. Results showed $15 \%$ of the total land area of Sta. Cruz, 12\% of Candelaria, 15\% of Masinloc, and 19\% of Palauig had high susceptibility to flooding. Barangays situated in these areas should be given priority in flood adaptation and mitigating programs.
\end{abstract}

\section{INTRODUCTION}

The Philippines, an archipelago in Southeast Asia, is one of the Countries most at risk to climate-induced hazards. This high risk can be drawn primarily from the country's high exposure to extreme weather events such as tropical cyclones. Strong typhoons represent one of the most prominent climate-related hazards in the Philippines and since the mid-20th century, extreme rainfall intensity and frequency have both increased (Franta et.al, 2016). The Philippines experiences an average of 20 cyclones a year that form over the Pacific Ocean which cause flooding in many parts of the country. Flood is defined as extremely high flows or levels of rivers, lakes, ponds, reservoirs and any other water bodies, whereby water inundates outside of the water bodies area (Smith et, al., 1998). Flooding also occurs when the sea level rises extremely or above coastal lands due to tidal sea and sea surges. In many regions and countries, floods are the most damaging phenomena that affect the social and economic conditions of the population (Smith et.al, 1998).

Zambales is one of the provinces prone to flooding. It is a province situated in Central Luzon, bounded on the north by Pangasinan, Tarlac and Pampanga on the east; Bataan on the south; and West Philippine Sea on the west. It has an aggregate area of $3714.40 \mathrm{~km} 2$ with two pronounced seasons: dry (October to June) and wet (July to September) (Taguiam et.al, 2016). Flooding in Sta. Cruz, Candelaria, Masinloc, and Palauig, Zambales is due to overflow of rivers especially those areas near the Sta. Cruz River, Bayto

River, Lauis River, Masinloc River, Salaza River, and Alwa River. In August 2013, Masinloc, Zambales was placed under the state of calamity due to flooding caused by Typhoon Labuyo and most barangays experienced flash floods. This typhoon not only displaced residents but also destroyed roads and bridges and the most affected were those living in lowlying areas (Farin et.al, 2017). In September 2018, Typhoon Ompong hit the province of Zambales and affected the northernmost town of Sta. Cruz where 992 families were displaced. In the town of Candelaria, 215 families were evacuated, 200 families in the town of Masinloc, and 23 families in Palauig, Zambales (Rappler 2018).

Flood hazard assessment and mapping can be done with the help of Geographic Information System (GIS) technology. It allows spatial analysis as well as to generate the modeling for a flood hazard phenomenon. GIS is an important tool to do data capture, input, manipulation, transformation, visualization, combination, analysis, and modeling and output (Marfai, 2003). Flood hazard assessment and mapping is used to identify areas at risk of flooding, and consequently to improve flood risk management and disaster preparedness. Also, flood hazard assessments can be further expanded to assess specific risks, which take into consideration the socioeconomic characteristics (e.g. industrial activities, population density, and land use) of the exposed areas (Armenakis et.al, 2017).

The main objective of this study was to generate flood hazard maps on the four northern municipalities of Zambales, namely, Sta. Cruz, Candelaria, Masinloc and Palauig, through GIS technology.

\section{STUDY AREA}

Four municipalities in Zambales such as Sta. Cruz, Candelaria, Masinloc, and Palauig were selected as the study areas (Figure 1). The study areas are bounded on the north by the municipality of Infanta, Pangasinan, on the south by Botolan, Zambales, on the east by the province of Tarlac, and on the west by the Philippine West Sea. Sta. Cruz has total land area of 43,846 hectares including the Hermana Mayor and Hermana Menor islands. It is composed of 25 barangays; 11 of these are categorized as coastal barangays. It has a total land area of 
43,846 hectares and has a coastline of 15 kilometers. Candelaria is bounded by the foot of Zambales mountain range on the east, Philippine West Sea on the west and by the municipalities of Sta. Cruz and Masinloc on the north and south, respectively. It has a total land area of 38,359.19 hectares with an estimated coastline of 13.5 kilometers. It is subdivided into 16 barangays and eight of them are classified as coastal barangays. Masinloc is bounded on the north by Candelaria, on the east by Mt. Masinloc, on the south by the towns of Palauig and Iba, and on the west by Oyon and Masinloc Bays. It has an aggregate land area of 30,600 hectares and a total coastline of 42.2 kilometers including the San Salvador Island. Palauig was founded in 1870 and inhabited by the Aeatas. It is bounded on the south by Iba and on the north by Masinloc. It has 19 barangays, 13 are categorized as coastal barangays (Taguiam et.al, 2016). Palauig has a total land area of 31,000 hectares and an estimated coastline of 12 kilometers including Magalawa Island.

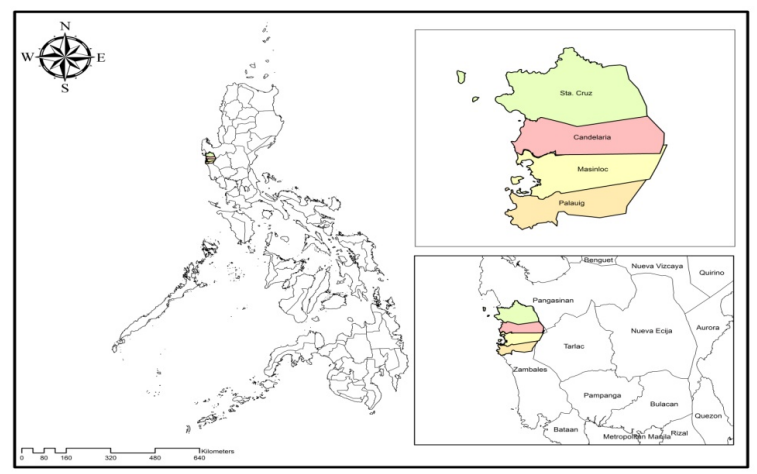

Figure 1. Geographic location of the study areas

\section{METHODOLOGY}

Satellite image (Figure 2) was downloaded through SASPlanet software, free software for viewing and downloading highresolution satellite imagery and conventional maps. The elevation, slope, soil type, land classification, and distance from the river data were used in making the flood hazard maps. The elevation map (Figure 3) and data were downloaded from Philippine Geographic Information System (PhilGIS), slope map (Figure 4), soil map (Figure 5) and data were obtained from the Department of Agriculture-Bureau of Agricultural Research, and the land cover map (Figure 6) and distance from the river map (Figure 7) were processed through Arcmap. The municipal and barangay boundary shapefiles used in the study were obtained from their respective Municipal Planning and Development Offices (MPDOs).

The administrative boundaries were subdivided into onehectare grid to calculate the percentage of the total land affected by flooding per barangay and in the whole municipality, and to ensure that scoring of flood hazard susceptibility will be very specific in that particular area. The elevation, slope, soil type, land cover, and distance from the river maps were the factors considered in generating flood hazard maps and were processed through ArcGIS raster calculator.

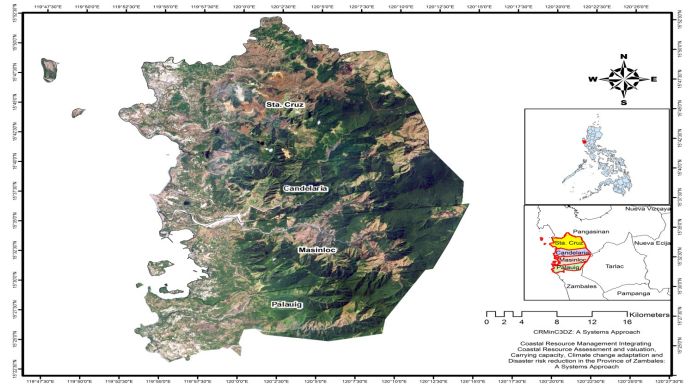

Figure 2. Satellite image of the study area

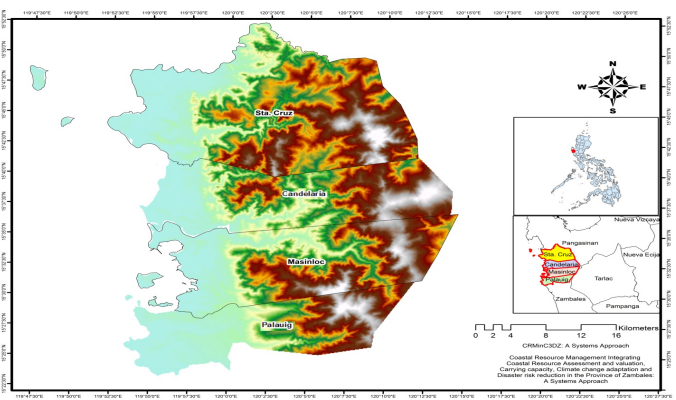

Figure 3. Elevation map of the study area

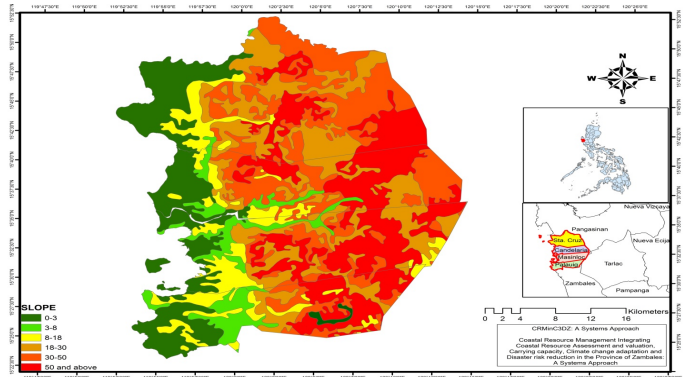

Figure 4. Slope map of the study area

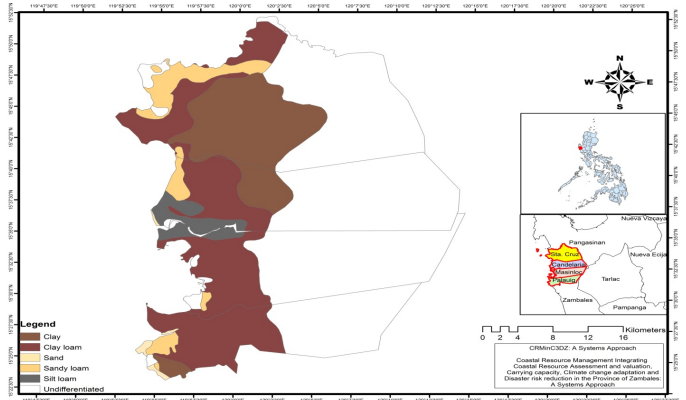

Figure 5. Soil map of the study area 


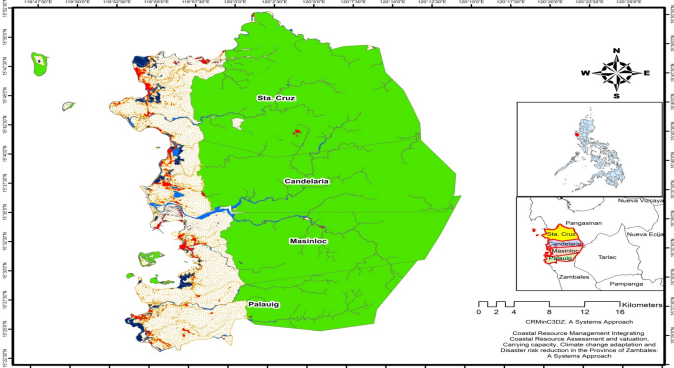

Figure 6. Land cover map of the study area

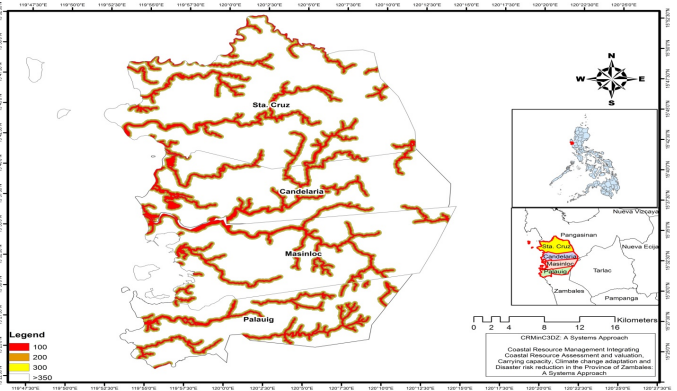

Figure 7. Distance from the river map of the study area

Table 1 shows the scoring of attributes for flood susceptibility index of the study area. The five factors (slope, soil type, land cover, distance from the river, and elevation) were reclassified into $0,1,2$, and 3 depending on their degree which can influence flooding.

\begin{tabular}{|c|c|c|c|c|c|}
\hline \multicolumn{2}{|c|}{ Slope (\%) } & \multicolumn{2}{|l|}{ Soil Type } & \multicolumn{2}{|l|}{ Land Cover } \\
\hline $30-50 \%$ & 0 & Sand & 0 & Forest/Coastline & 0 \\
\hline $18-30 \%$ & 1 & Sandy Loam & 1 & Agricultural & 1 \\
\hline $8-18 \%$ & 2 & Silt Loam & 2 & Inland Water & 2 \\
\hline $0-8 \%$ & 3 & Clay Loam & 3 & River/Built-up & 3 \\
\hline \multicolumn{2}{|c|}{$\begin{array}{l}\text { Distance from } \\
\text { the river }(\mathrm{m})\end{array}$} & \multicolumn{2}{|l|}{ Elevation } & & \\
\hline$>300 \mathrm{~m}$ & 0 & $0-100$ & 3 & & \\
\hline $300 \mathrm{~m}$ & 1 & $101-250$ & 2 & & \\
\hline $200 \mathrm{~m}$ & 2 & $251-500$ & 1 & & \\
\hline $100 \mathrm{~m}$ & 3 & $>500$ & 0 & & \\
\hline
\end{tabular}

Table 1. Scoring of attributes for flood susceptibility generation

The weights of these factors were drawn from the ten (10) experts and underwent the Analytic Hierarchy Process (AHP), adopted from Saaty (1980). Numbers indicate the priority vector that were generated from the AHP and used in assigning weights to the different factors influencing flood hazard susceptibility of the study area (Table 1). The result of the AHP was used for the formulation of equation to be used for flood susceptibility generation (1). This equation was inputted to raster calculator to generate the flood susceptibility for each municipality.

$F S=0.36 E+0.21 S+0.18 S T+0.14 L C+0.11 D R$

Where:

FS = Flood Susceptibility; E = Elevation; $\mathrm{S}=$ Slope; $\mathrm{ST}=$ Soil Type; $\mathrm{LC}=$ Land Cover; DR $=$ Distance from the River
Flood susceptibility index scores were categorized as 0 for no susceptibility, 1 for low susceptibility, 2 for moderate susceptibility, and 3 for high susceptibility.

\begin{tabular}{|c|c|c|c|c|c|c|}
\hline Factors & $\begin{array}{c}\text { Eleva } \\
\text { tion }\end{array}$ & $\begin{array}{c}\text { Slop } \\
\text { e }\end{array}$ & $\begin{array}{c}\text { Soil } \\
\text { Text } \\
\text { ure }\end{array}$ & $\begin{array}{c}\text { Lan } \\
\text { d } \\
\text { Use }\end{array}$ & $\begin{array}{l}\text { Distance } \\
\text { from the } \\
\text { River }\end{array}$ & $\begin{array}{c}\text { Prior } \\
\text { ity } \\
\text { Vecto } \\
\mathbf{r}\end{array}$ \\
\hline Elevation & 0.30 & 0.36 & 0.28 & $\begin{array}{c}0.2 \\
0\end{array}$ & 0.22 & 0.36 \\
\hline Slope & 0.13 & 0.13 & 0.29 & $\begin{array}{c}0.2 \\
4 \\
\end{array}$ & 0.17 & 0.21 \\
\hline Soil type & 0.13 & 0.07 & 0.10 & $\begin{array}{c}0.2 \\
5 \\
\end{array}$ & 0.23 & 0.18 \\
\hline $\begin{array}{l}\text { Land } \\
\text { Cover } \\
\end{array}$ & 0.11 & 0.04 & 0.05 & $\begin{array}{c}0.0 \\
7 \\
\end{array}$ & 0.19 & 0.14 \\
\hline $\begin{array}{c}\text { Distance } \\
\text { from the } \\
\text { River }\end{array}$ & 0.11 & 0.07 & 0.04 & $\begin{array}{c}0.0 \\
4 \\
\end{array}$ & 0.05 & 0.11 \\
\hline
\end{tabular}

Table 2. Results of Analytic Hierarchy Process on the factors influencing flood susceptibility

For field validation, five (5) points per barangay were selected randomly from the total number of grids (Figure 8). This served as validation points wherein values generated were counterchecked in the field

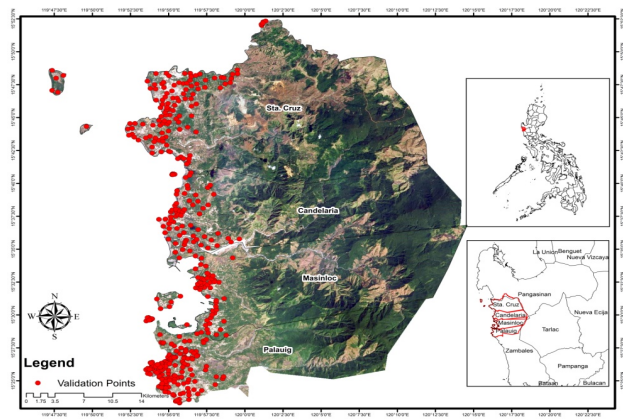

Figure 8 . Validation points of the study areas

\section{RESULTS AND DISCUSSION}

Flood hazard susceptibility is categorized into four (4) namely no, low, moderate, and high susceptibility to flooding. In Sta. Cruz, Zambales, fifteen percent (15\%) of the total land area had portions with high susceptibility to flooding, fifteen percent $(15 \%)$ with moderate susceptibility, thirty three $(33 \%)$ with low susceptibility, and thirty seven percent $(37 \%)$ not affected by flooding. Percentage was computed based on the number of grids over the total number of grids in the municipality (Table 3). Percentage of area affected by flood were shown in Table 4, and results revealed that seventeen (17) out of twenty four (24) barangays (Bayto, Biay, Bolitoc, Gama, Guinabon, Guisguis, Lipay, Lomboy, Lucapon North, Lucapon South, Malabago, Naulo, Pagatpat, Poblacion, Sabang, San Fernando, and Tubo-tubo North) were highly susceptible to flooding. Barangay Bangcol, Bulawon, Canaynayan, Pamonoran, and Tubo-tubo North were moderately susceptible. These barangays were located near the bank of the river and coast hence they were easily affected by floods. Barangay Babuyan was the least susceptible to flooding because of its high elevation (Figure 9). Distance from the river and coast 
have significant impacts on the flood. Also, the soil texture in Sta. Cruz is clay and clay loam which has a lesser infiltration rate compared to sandy soil.

\begin{tabular}{|l|c|c|}
\hline & Number of grids & Percentage (\%) \\
\hline Not Affected & 19,502 & $\mathbf{3 7}$ \\
\hline Low & 17,400 & $\mathbf{3 3}$ \\
\hline Moderate & 8,234 & $\mathbf{1 5}$ \\
\hline High & 8,206 & $\mathbf{1 5}$ \\
\hline Total & $\mathbf{5 3 , 3 4 2}$ & $\mathbf{1 0 0}$ \\
\hline
\end{tabular}

Table 3. Total number of grids in Sta. Cruz, Zambales

\begin{tabular}{|l|c|c|c|c|}
\hline \multicolumn{1}{|c|}{ Barangay } & $\begin{array}{c}\text { Not } \\
\text { Affected }\end{array}$ & Low & Moderate & High \\
\hline 1. Babuyan & 4.9 & 62.9 & 24 & 8.2 \\
\hline 2. Bangcol & 0 & 0 & 80.7 & 19.3 \\
\hline 3. Bayto & 0 & 0 & 0 & 100 \\
\hline 4. Biay & 0 & 0 & 25.7 & 74.3 \\
\hline 5. Bolitoc & 0 & 0 & 9.2 & 90.8 \\
\hline 6. Bulawon & 0 & 0 & 65.1 & 34.9 \\
\hline 7. Canaynayan & 0 & 0 & 69.7 & 30.4 \\
\hline 8. Gama & 0 & 0 & 19.4 & 80.6 \\
\hline 9. Guinabon & 0 & 8.7 & 40.7 & 50.6 \\
\hline 10. Guisguis & 0 & 0 & 41.3 & 58.7 \\
\hline 11. Lipay & 0 & 0 & 11.8 & 88.2 \\
\hline 12. Lomboy & 0 & 0 & 34 & 66 \\
\hline 13. Lucapon North & 0 & 0 & 26.5 & 73.5 \\
\hline 14. Lucapon South & 0 & 0 & 45 & 55 \\
\hline 15. Malabago & 0 & 0 & 20.8 & 79.2 \\
\hline 16. Naulo & 0 & 0 & 0 & 100 \\
\hline 17. Pagatpat & 0 & 0 & 47.2 & 52.8 \\
\hline 18. Pamonoran & 0 & 0 & 73.7 & 26.3 \\
\hline 19. Poblacion & 0 & 0 & 38.9 & 61.1 \\
\hline 20. Sabang & 0 & 0 & 0 & 100 \\
\hline 21. San Fernando & 0 & 0 & 22 & 78 \\
\hline 22. Tabalong & 0 & 0 & 66.3 & 33.7 \\
\hline 23. Tubo-tubo North & 0 & 0 & 43.7 & 56.3 \\
\hline 24. Tubo-tubo South & 0 & 0 & 47 & 53 \\
\hline Tabl Perceng $0 f$ & $0.7 f e d$ & & \\
\hline
\end{tabular}

Table 4. Percentage of area affected by flood in Sta. Cruz

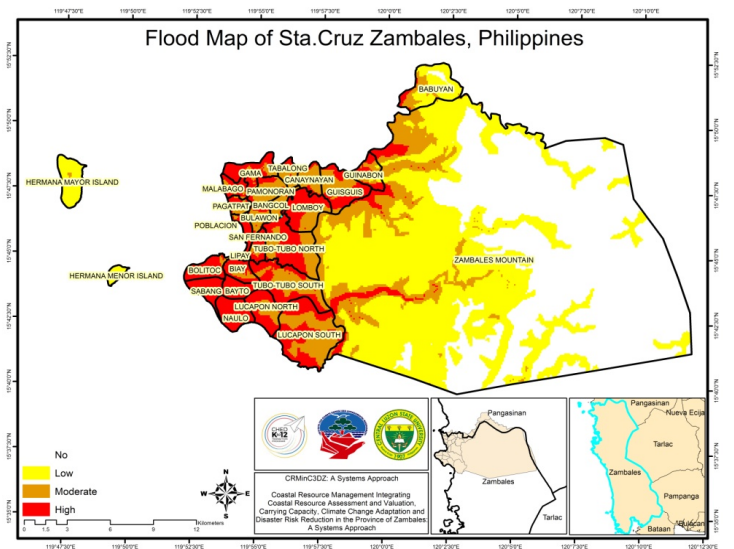

Figure 9. Flood hazard susceptibility of Sta. Cruz, Zambales

Table 5 shows the total number of grids in Candelaria, Zambales. Twelve percent $(12 \%)$ of the total land area of Candelaria was highly susceptible to flood, nineteen percent (19\%) with moderate susceptibility, twenty nine (29\%) was least susceptible, and thirty nine percent $(39 \%)$ was not affected by flooding. Table 6 shows that eleven (11) out of sixteen (16) barangays were found to be highly susceptible to flood such as Barangay Babancal, Binabalian, Catol, Malabon, Malimanga, Pamibian, Panayonan, Poblacion, Sinabacan, Taposo, and Barangay Uacon. The remaining five barangays were moderately susceptible to flooding (Dampay, Lauis, Libertador, Pinagrelan, and Yamot) (Figure 10). These sixteen (16) barangays have low elevation and situated near the river and creeks that made them susceptible to flooding. Also, forest disturbances were observed that cause rain water from mountain areas flow throughout the municipality.

\begin{tabular}{|l|c|c|}
\hline & $\begin{array}{c}\text { Number of } \\
\text { grids }\end{array}$ & $\begin{array}{c}\text { Percentage } \\
(\%)\end{array}$ \\
\hline $\begin{array}{l}\text { Not } \\
\text { Affected }\end{array}$ & 14210 & $\mathbf{3 9}$ \\
\hline Low & 10716 & $\mathbf{2 9}$ \\
\hline Moderate & 7031 & $\mathbf{1 9}$ \\
\hline High & 4520 & $\mathbf{1 2}$ \\
\hline Total & $\mathbf{3 6 4 7 7}$ & $\mathbf{1 0 0}$ \\
\hline
\end{tabular}

Table 5. Total number of grids in Candelaria, Zambales

\begin{tabular}{|l|c|c|c|c|}
\hline \multicolumn{1}{|c|}{ Barangay } & Not Affected & Low & Moderate & High \\
\hline 1. Babancal & 0 & 0 & 22 & 78 \\
\hline 2. Binabalian & 0 & 0 & 35.5 & 64.5 \\
\hline 3. Catol & 0 & 0 & 41.5 & 58.5 \\
\hline 4. Dampay & 0 & 0 & 74.4 & 25.6 \\
\hline 5. Lauis & 0 & 0 & 87.5 & 12.5 \\
\hline 6. Libertador & 0 & 0 & 61.3 & 38.7 \\
\hline 7. Malabon & 0 & 0 & 41.4 & 58.6 \\
\hline 8. Malimanga & 0 & 0.3 & 40.6 & 59.1 \\
\hline 9. Pamibian & 0 & 0 & 13.5 & 86.5 \\
\hline 10. Panayunan & 0 & 3 & 2 & 95 \\
\hline 11. Pinagrelan & 0 & 0 & 78.8 & 21.2 \\
\hline 12. Poblacion & 0 & 0 & 4.4 & 95.6 \\
\hline 13. Sinabacan & 0 & 0 & 36.2 & 63.8 \\
\hline 14. Taposo & 0 & 0 & 30.5 & 69.5 \\
\hline 15. Uacon & 0 & 0.1 & 38.2 & 61.7 \\
\hline 16. Yamot & 0 & 0 & 51.2 & 48.8 \\
\hline
\end{tabular}

Table 6. Percentage of area affected by flood in Candelaria 


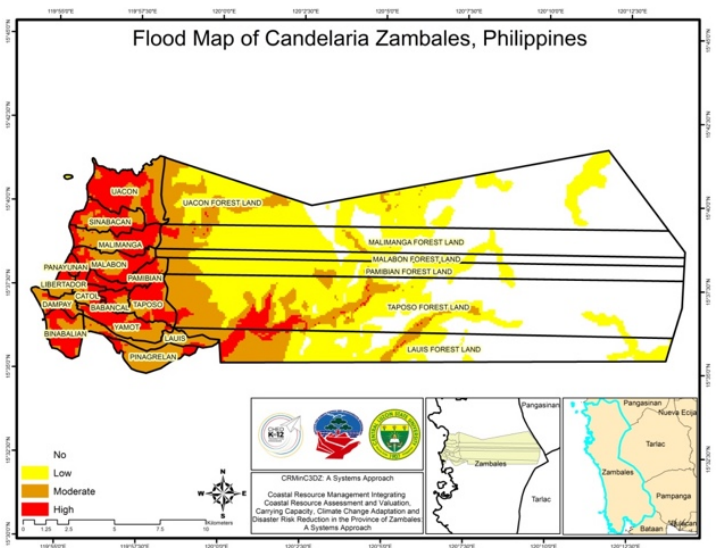

Figure 10. Flood hazard susceptibility of Candelaria, Zambales

For the flood hazard susceptibility of Masinloc, Zambales, Table 7 shows that $15 \%$ of total land area were found to be highly susceptible, $17 \%$ had moderate susceptibility, and $23 \%$ had low susceptibility, and forty five percent $(45 \%)$ had not affected by flooding. In terms of area affected, six (6) of the thirteen (13) barangays were highly susceptible to flooding (Baloganon, Bani, Collat, North Poblacion, South Poblacion, and Tapuac). These areas have poorly drained soil that produces increase surface run-off. Barangays Bamban and Sto. Rosario were moderately susceptible, and Barangay San Salvador was the least susceptible to flooding (Table 8). Majority of the areas of Barangays Inhobol, San Lorenzo, Sta. Rita, and Taltal were not affected by flooding (Figure 11).

\begin{tabular}{|l|c|c|}
\hline & Number of grids & Percentage (\%) \\
\hline $\begin{array}{l}\text { Not } \\
\text { Affected }\end{array}$ & 16014 & $\mathbf{4 5}$ \\
\hline Low & 8383 & $\mathbf{2 3}$ \\
\hline Moderate & 6036 & $\mathbf{1 7}$ \\
\hline High & 5276 & $\mathbf{1 5}$ \\
\hline Total & $\mathbf{3 5 7 0 9}$ & $\mathbf{1 0 0}$ \\
\hline
\end{tabular}

Table 7. Total number of grids in Masinloc, Zambales

\begin{tabular}{|l|c|c|c|c|}
\hline \multicolumn{1}{|c|}{ Barangay } & $\begin{array}{c}\text { Not } \\
\text { Affected }\end{array}$ & Low & Moderate & High \\
\hline 1. Baloganon & 1.5 & 10.9 & 30.4 & 57.2 \\
\hline 2. Bamban & 26.9 & 21.9 & 35.9 & 15.3 \\
\hline 3. Bani & 0 & 0 & 28.5 & 71.5 \\
\hline 4. Collat & 0 & 0 & 17.7 & 82.3 \\
\hline 5. Inhobol & 31.6 & 16.2 & 25.1 & 27.1 \\
\hline $\begin{array}{l}\text { 6. North } \\
\text { Poblacion }\end{array}$ & 0 & 0 & 0 & 100 \\
\hline $\begin{array}{l}\text { 7. San } \\
\text { Lorenzo }\end{array}$ & 62.7 & 20.4 & 12.1 & 4.8 \\
\hline $\begin{array}{l}\text { 8. San } \\
\text { Salvador }\end{array}$ & 0 & 100 & 0 & 0 \\
\hline $\begin{array}{l}\text { 9. South } \\
\text { Poblacion }\end{array}$ & 0 & 0 & 0 & 100 \\
\hline $\begin{array}{l}\text { 10. Sta. Rita } \\
\text { 11. Sto. }\end{array}$ & 45.4 & 24.7 & 11.1 & 18.8 \\
\hline
\end{tabular}




\begin{tabular}{|l|c|c|c|c|}
\hline \multicolumn{1}{|c|}{ Barangay } & Not Affected & Low & Moderate & High \\
\hline 1. Alwa & 0 & 0 & 38 & 62 \\
\hline 2. Bato & 0 & 0 & 12 & 88 \\
\hline 3. Bulawen & 0 & 0 & 80.3 & 19.7 \\
\hline 4. Cauyan & 0 & 0 & 68.5 & 31.5 \\
\hline 5. East Poblacion & 0 & 0 & 0 & 100 \\
\hline 6. Garreta & 0 & 0 & 0 & 100 \\
\hline 7. Libaba & 0 & 0 & 0 & 100 \\
\hline 8. Liozon & 0 & 0 & 9.7 & 90.3 \\
\hline 9. Lipay & 0 & 0 & 32.7 & 67.2 \\
\hline 10. Locloc & 0 & 0 & 0 & 100 \\
\hline 11. Macarang & 0 & 0 & 7.7 & 92.3 \\
\hline 12. Magalawa & 0 & 0 & 100 & 0 \\
\hline 13. Pangolingan & 0 & 0 & 80.1 & 19.9 \\
\hline 14. Salaza & 53.6 & 29.7 & 13.7 & 3 \\
\hline 15. San Juan & 0 & 0 & 9.2 & 90.8 \\
\hline 16. Santo Nino & 0 & 0 & 62.5 & 37.5 \\
\hline 17. Santo Tomas & 0 & 0 & 41.2 & 58.8 \\
\hline 18. San Vicente & 0 & 0 & 23 & 77 \\
\hline 19. West & & & & \\
Poblacion & 0 & 0 & 0 & 100 \\
\hline
\end{tabular}

Table 10. Percentage of area affected by flood in Palauig

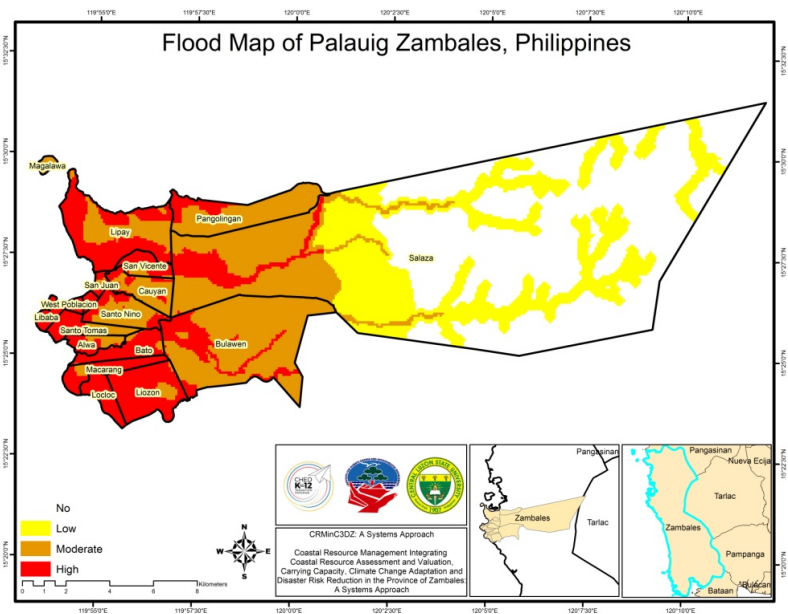

Figure 12. Flood hazard susceptibility of Palauig, Zambales

\section{CONCLUSION}

Based on the flood hazard assessment, the municipality of Palauig was found to be the most prone or susceptible to flooding with nineteen percent $(19 \%)$ of the total land area compared to the municipality of Sta. Cruz, Candelaria, and Masinloc with fifteen percent $(15 \%)$, twelve percent $(12 \%)$, and fifteen percent (15\%) respectively. Sixteen (16) barangays in Sta. Cruz, eleven (11) in Candelaria, six (6) in Masinloc, and thirteen (13) barangays in Palauig, Zambales are mostly prone to flooding. Barangays classified with high susceptibility to flooding are located in low-lying areas and the rivers or creeks. These barangays should be given priority in flood adaptation and mitigating programs.

\section{RECOMMENDATION}

Barangays situated in the high flood susceptible zone require special attention from the government to take appropriate actions to prevent and mitigate future flood occurrence.

\section{ACKNOWLEGDMENT}

The authors are grateful to the funding agency, Commission on Higher Education (CHED) DARE-TO K12 Program for providing funds to conduct this study and for the trust and confidence especially in our abilities to come up with significant outputs and in the accomplishment of our objectives. Sincere gratitude also to LGUs and communities in Sta. Cruz, Candelaria, Masinloc, and Palauig, Zambales for the support provided in conducting the study.

\section{REFERENCES}

AJIN. R. S., R. R. KRISHNAMURTHY, M. JAYAPRAKASH, and VINOD. P. G, 2013, Flood hazard assessment of Vamanapuram River Basin, Kerala, India: An approach using Remote Sensing \& GIS techniques, Department of Applied Geology, School of Earth and Atmospheric Sciences, University of Madras, Chennai, Tamilnadu, India.

ARMENAKIS C., E. XINHENG DU, S. NATESAN, R. A. PERSAD, and Y. ZHANG, 2017, Flood Risk Assessment in Urban Areas Based on Spatial Analytics and Social Factors, Geomatics Engineering, Department of Earth \& Space Science \& Engineering, Lassonde School of Engineering, York University, Toronto, Canada.

FARIN, E., A. CO, and A. FARIN, 2017, Flood Disaster Preparedness and Practices of the Public Elementary Schools in Selected Flood - Prone Areas in Zambales, Philippines, Ramon Magsaysay Technological University, Iba, Zambales, Philippines.

FRANTA, B., H. A. R. QUIAOIT, D. LO, and G. NARISMA, 2016, Climate Disasters in the Philippines: A Case Study of Immediate Causes and Root Drivers from Cagayan de Oro, Mindanao and Tropical Storm Sendong/Washi, Belfer Center for Science and International Affairs, Cambridge, Mass: Harvard University, USA.

MARFAI, MUH ARIS, 2003, GIS Modelling of River and Tidal Flood Hazards in a Waterfront City, Case Study: Semarang City, Central Java, Indonesia.

RAPPLER， 2018， https://www.rappler.com/nation/212069families-evacuated-zambales-typhoon-ompong

RINCO D., U. KHAN, and C. ARMENAKIS, 2018, Flood Risk Mapping Using GIS and Multi-Criteria Analysis: A Greater Toronto Area Case Study, Geomatics Engineering, Department of Earth and Space Science and Engineering, Lassonde School of Engineering, York University, Toronto, Canada.

SMITH, K. and R. WARD, 1998, Floods: Physical Processes and Human Impacts, John Wiley and Sons, Chichester, USA. 
SNEAD, DANIEL BALDWIN, 2000, Development and Application of Unsteady Flood Models Using Geographic Information Systems, Department Report, Master of Science in Engineering, The University of Texas at Austin, USA.

TAGUIAM, C. and C. QUIAMBAO, 2016, Rural Coastal Households' Cognition of Sea Level Rise: The case of Zambales, Philippines. 